\title{
REVIEW
}

\section{Evidence and Strategies for Inclusion of Emotional Intelligence in Pharmacy Education}

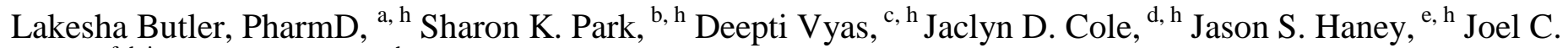
Marrs, ${ }^{\text {f, h,i Evan Williams }}$ g, h

${ }^{a}$ Southern Illinois University, School of Pharmacy, Edwardsville, Illinois

${ }^{\mathrm{b}}$ Notre Dame of Maryland University, School of Pharmacy, Baltimore, Maryland

${ }^{\mathrm{c}}$ University of the Pacific, School of Pharmacy, Stockton, California

${ }^{\mathrm{d}}$ University of South Florida, Taneja College of Pharmacy, Tampa, Florida

${ }^{\mathrm{e}}$ Medical University of South Carolina, College of Pharmacy, Charleston, South Carolina

${ }^{\mathrm{f}}$ University of Colorado Anschutz Medical Campus, School of Medicine, Aurora, Colorado

${ }^{g}$ Roseman University of Health Sciences, College of Pharmacy, Henderson, Nevada

${ }^{\text {h }}$ AACP Council of Faculties, Faculty Affairs Committee, Arlington, Virginia

${ }^{\mathrm{i}}$ Editorial Board Member, American Journal of Pharmaceutical Education, Arlington, Virginia

Corresponding Author: Lakesha M. Butler, Southern Illinois University Edwardsville, School of Pharmacy, 200 University Park Dr., Edwardsville, IL 62026. Tel: 618-650-5119. Email: 1wiley@ siue.edu

Submitted April 2, 2021; accepted September 17, 2021; ePublished October 2021

Objective. This integrative review summarizes the literature addressing emotional intelligence among healthcare professionals and students in order to better define and incorporate it into the pharmacy curricula.

Findings. Emotional intelligence is an essential attribute for relationship building, stress management, and self-regulation. It is imperative for pharmacy students to develop and improve their emotional intelligence in order to support the development of successful relationships with patients, pharmacy colleagues, and other healthcare providers. In addition, awareness of one's own biases and emotions can help regulate behaviors so as to facilitate enhanced communications with others. There is increasing evidence that emotional intelligence can influence academic success, ability to provide compassionate and competent patient care, ability to lead and influence others, and manage stress, all of which are extremely important in pharmacy education. Educators can help learners develop emotional intelligence by designing activities that directly identify and target areas of weakness while leveraging areas of strength.

Summary. This article discusses key background studies on emotional intelligence in the health professions literature and identifies specific methods and strategies to develop learners' emotional intelligence within the curriculum.

Keywords: emotional intelligence; social emotional competence; assessment; pharmacy education

\section{INTRODUCTION}

Pharmacists routinely encounter complex and emotionally fraught patient care situations, which comprise of interpersonal conflict, dichotomy between beliefs and work ethic, and stressful work environments. Accurately identifying one's own emotions and regulating those emotions can promote adaptive behaviors to effectively navigate complex situations. Emotional intelligence (EQ) is defined as the ability to accurately monitor and discern emotions, within oneself and others, and to use this information to guide one's own thoughts and actions. ${ }^{1}$ This term was first coined in a landmark article by Salovey and Mayer ${ }^{1}$ that introduced a framework for evaluating emotions within the construct of social intelligence. Later, Mayer and colleagues ${ }^{2}$ proposed the Four Branch Model of EQ that includes the ability to: 1) accurately perceive emotions in oneself and others; 2) utilize these emotions to facilitate thinking; 3) understand all aspects of emotion, including language and signals; and 4) manage emotions to obtain a specific goal or outcome. Evolution of the perspectives and interpretation regarding EQ has resulted in differing viewpoints; categorizing EQ as either the ability to theoretically understand emotions and emotional functions, known as the ability-based model or selfreport measures which identify typical behaviors in relevant emotional situations, known as the trait model. ${ }^{3}$ Subsequent authors and scholars introduced the inclusion of positive traits and attributes into EQ, including empathy and emotional self-awareness, which eventually led to the mixed-model theory of EQ. ${ }^{3}$ Despite the differences, at the core of each model is the basis that EQ allows one to perceive one's own emotions, regulate that emotion, and understand others' emotions to facilitate one's reaction and behaviors. ${ }^{3}$ However, there is currently no one-size-fits-all model. The purpose of this 
integrative review is to summarize the literature addressing EQ among healthcare professionals and students in order to better define and make an informed decision when incorporating into the pharmacy curricula.

\section{Emotional Intelligence in the Health Professions}

Several studies have highlighted the importance of EQ in the medicine and nursing literature (Table 1). ${ }^{4-21}$ In medicine, higher EQ has been linked to better patient outcomes, better stress management, and improved wellbeing. Higher levels of EQ in physicians enhances patient outcomes and satisfaction. ${ }^{5,22}$ An assessment of general surgery medical residents reported that EQ scores positively correlated with well-being, and inversely correlated with depression, emotional exhaustion, and depersonalization. ${ }^{13}$ In the nursing literature, Rode and colleagues ${ }^{18}$ found a relationship between EQ and performance on the National Council Licensure Examination (NCLEX) and the Kaplan Nursing Assessment Test; students with higher EQ performed better on both assessments. Similarly, Sharon and colleagues ${ }^{19}$ found that the level of EQ positively correlated with academic success in nursing studies.

Similar to the medical and nursing literature, several studies have examined EQ among pharmacists and pharmacy students (Table 1). ${ }^{4-21}$ Observational studies among pharmacy students have primarily focused on the impact of EQ on overall wellness, empathy, and communication and leadership skills. Moreno-Fernandez ${ }^{23}$ reported protective features related to EQ with fewer students reporting burnout, cynicism, and exhaustion after EQ workshops. Among a sample of pharmacists and pharmacy students, EQ as measured by the emotional intelligence scale (EQS) improved the effects of negative autistic-like traits (ALT) on empathy a and mental health, suggesting that EQ may be helpful for the adverse effects of ALT. ${ }^{11}$ Haight and colleagues ${ }^{9}$ found that the Emotional Intelligent Leadership Inventory (EILI) had primary connections with the interprofessional communication and leadership capacity of students, suggesting that the EILI can be used to assess student EQ and leadership potential. In the pharmacy skills arena, awareness of emotions can help improve professional communication. ${ }^{7,8}$ Galal and colleagues ${ }^{7}$ reported that observer ratings on the influence and connection aspect of social emotional competence, as measured by the social and emotional development inventory (SED-I), were correlated with performance. These beneficial correlations prompted interventional studies that focused on improving EQ through leadership programming or co-curricular activities. ${ }^{7-10,14,20,24,25}$ Students who participated in a three-year leadership degree option at the University of Oklahoma College of Pharmacy reported improved Emotional Intelligence Appraisal scores at end of the program. ${ }^{20}$ In the co-curriculum, Buckley ${ }^{24}$ showed improvement in leadership skills through sustained reflections, topic discussions, and regular feedback regarding EQ. In addition, EQ development for practicing pharmacists through leadership programming has been demonstrated. Hall and colleagues ${ }^{10}$ reported that pharmacists who had completed the American Society of Health-System Pharmacists Pharmacy Leadership Academy had significantly higher mean Emotional Quotient Inventory, version 2.0 (EQ-i 2.0) scores than those who were just enrolling.

\section{Emotional Intelligence Tools and Assessments}

There is a lack of agreement regarding a standardized assessment tool in EQ research. ${ }^{3}$ Several tools for measuring emotional intelligence have been described in the literature. ${ }^{26-40}$ These assessments are generally divided by the various model theories of emotional intelligence: ability, trait, and mixed. As these competing views of the characterization of EQ continue to further diverge, it becomes less likely that any concordance regarding a standardized assessment method for EQ in health education will be reached. ${ }^{3}$

\section{Choosing an Assessment Tool}

When selecting an assessment tool, choosing between ability-based versus trait-based versus mixed measures may be an important first step. Ability-based measures are useful when measurement of the student's ability to identify emotions is being assessed. However, measures based on the EQ ability construct have difficulty distinguishing between EQ skills gleaned from experience versus skills developed independent of prior learning. This confounds the ability to assess the impact of curricular interventions on EQ development in students. In most cases, ability-based measures cannot be falsified as there is a right answer to each question, similar to IQ tests, which have the advantage of eliminating selfreport bias. ${ }^{3}$ However, ability-based measures do not predict outcomes; just because a test-taker understands an emotion, does not mean they will be able to take appropriate action in a given situation. Furthermore, the ability to correctly identify emotions does not necessarily translate to actual behaviors, which limits the utility of ability-based measures in assessing EQ. ${ }^{3}$ Possible utilization of ability-based EQ assessments could be in introductory communications courses, which require foundational understanding of emotions and how they work. Other uses may be in leadership courses where students need to have a good theoretical understanding of emotions. Ability-based assessments may also be useful in personnel selection as they can be good predictors of good managerial skills. 
Trait-based measures have the distinct advantage of assessing student EQ based on typical behavior in the past which can be a predictor of future performance. ${ }^{3}$ This can be useful in situations that are intervention-based and require students to identify weaknesses prior to training/coaching. Trait-based measures are useful in situations where the researcher needs to measure emotional self-efficacy. However, trait-based measures are prone to self-report bias, which may limit their utility in situations where the test-taker may hesitate to report negative traits or may opt for a socially desirable response, such as during admissions or job interviews. ${ }^{3}$ In addition, trait-based measures rely on test-taker selfawareness and good judgment, which is not always a given.

Mixed-model assessments combine multiple areas of measurements that are social-emotional EQ qualities including personality, motivation, emotionally-based skills, and other areas. ${ }^{27}$ The benefit of using a mixed assessment is the ability to assess multiple EQ qualities in one tool and combining them together into an EQ percentage like IQ instead of administering multiple tools. Mixed-model EQ assessments are typically heterogenous in nature and are measured via self-reports and/or rater reports which makes self-report bias more likely. Despite this potential bias, mixed assessments are becoming more commonly used due to the measurement of multiple EQ qualities in a single tool. Selection of the appropriate assessment tool will largely depend on the purpose of the assessment. Table 2 provides a detailed summary of select EQ assessment tools.

\section{Ability-Based Assessments}

The Mayer-Salovey-Caruso Emotional Intelligence Test (MSCEIT V2.0) is the most popular ability-based tool and is available from Multi-Health Systems (MHS) of Toronto, Canada. ${ }^{30}$ The test is available as an adult and youth research version. MHS scores the test based on the standardization sample and expert criteria, with an option for researchers to develop their own independent norms.

The Genos Emotional Intelligence Inventory (Genos EI) is a behavior-based assessment that was created to assess professionals' typical workplace behavior. ${ }^{31}$ Three versions of Genos EI (ie, short, concise, and full inventories) are available in both self-report and rater-report format. A development report is provided along with scoring which identifies strengths and opportunities for development along with personalized suggestions for EQ development.

\section{Trait-Based Assessments}

The Trait Meta-Mood Scale (TMMS) is largely outdated while widely assessed. It was modified from 30 to 24 self-reported items in multilingual versions rated on a Likert scale of one (strongly disagree) to five (strongly agree) and divided into three subscales that are classified in either the low, middle or high score range. ${ }^{32}$ The scale is available online through the American Psychological Association (APA) PsycNet free for members or those with institutional access. The average and inter-element correlations both showed a moderately positive relationship for each of the sub-scales. The Trait Emotional Intelligence Questionnaire (TEIQue) provides a comprehensive assessment of an individual's emotional self-efficacy. ${ }^{26,33}$ TEIQue conceptualizes EQ as a personality trait to be viewed in the context of trait EQ theory. It does not measure emotional intelligence per se, but the scoring represents typical behavior or self-regard. The instrument has strong reliability and is extensively validated. ${ }^{26}$ The original version can be completed within 30 minutes. Additional adaptations are available such as the short form (TEIQue-SF) and peer or 360-degree ratings (TEIQue $360^{\circ}$ ).

The Assessing Emotions Scale (AES), also called the Emotional Intelligence Scale, Self-Report Emotional Intelligence Test (SREIT), Schutte Self-Report Emotional Intelligence Test (SSEIT), Schutte Emotional Intelligence Scale, or Schutte Self-Report Inventory (SSRI), is a measure of trait emotional intelligence based on Salovey and Mayer's original model. ${ }^{1,34}$ The assessment is closely associated with the Emotional Quotient-Inventory model and relates to the four branch model of EQ. ${ }^{2}$ Individualized reports are not available, instead total scale scores are calculated by reverse coding three items, and then summing all items. Scores can range from 33 to 165, with higher scores indicating stronger emotional intelligence. AES has strong markers of reliability.

\section{Mixed Assessments}

The Emotional Quotient Inventory 2.0 (EQ-i 2.0) is a self-reporting instrument based on the mixed model that assesses social and emotional traits and their influence on an individual's well-being. ${ }^{35}$ The self-administered instrument is available from MHS Inc. and uses short self-statements rated on a 5-point Likert scale. ${ }^{27}$ Various report options are available, including but not limited to a detailed, personalized client report with strategies for action, a development plan, and a higher education report for the student and counselor to help foster academic and life success. However, 15 subscales may make this tool esoteric, too complex to easily recall, and time-consuming. Multiple tests of validity are incorporated into the EQ-i 2.0, including an inconsistency index to assess for randomness in responses and positive- and negative-impression scales to indicate excessive positive or negative responses, respectively. The EQ-i 2.0 instrument 
shows strong reliability, both internal consistency and test-retest. ${ }^{36}$ The 360 multi-rater measure (EQ-360) is available as a complimentary assessment that combines self-assessment with the perceptions of others who know the individual well. Social and Emotional Development Inventory (SED-I) is a mixed model designed to better understand and improve the developmental path of social and emotional ability for students in higher education. ${ }^{37,38}$ This model includes focuses on a student's ability to identify emotional cues, process emotional information, and employ emotional knowledge to adapt to social challenges in higher education. Using the SED-I companion tool, students rate how often 48 different statements are true of them using a seven-point scale, ranging from one (very rarely) to seven (very often). The four factors of the SED model are represented equally, and each factor contains three reverse-scored items. After adjusting for reversescored items, factor scores are derived as well as a total score. These scores generate a student's rank order preference of the four factors to identify areas of social and emotional competence and create developmental learning agendas. SED-I has excellent reliability for the overall scale and good reliability for the factor scales. Test-retest reliability over a three to seven-month period was stronger for the factors of influencing change and connection to others versus self-awareness and consideration of others $(r=0.74,0.79,0.36$, and 0.53 , respectively).

The Personal-Interpersonal Competence Assessment (PICA) is a refinement to the SED-I to better align the operational instrument with the conceptual framework. ${ }^{39}$ Students rate how often each statement is true of them using a nine-point scale, ranging from one (never) to nine (always). This assessment model includes the same four factors of the SED with each factor represented equally but without reverse-scored items. Factor scores and a total score are derived as well as a student's rank order preference of the four factors to identify personal-interpersonal competence. Personalinterpersonal competence is the increase in emotional knowledge capacity and social-behavioral options to achieve desirable, sustainable outcomes. The PICA demonstrates strong reliability.

The Emotional Intelligence 2.0 is popularized as a book resource that utilizes the Emotional Intelligence Appraisal assessment and is intended to increase EQ through 66 strategies. ${ }^{28}$ The test aims to increase EQ from a baseline assessment, an online report with a goal-tracking system that suggest how to improve EQ skills, and automatic reminders. The same authors developed the Emotional Intelligence Appraisal, Me Edition which is self-administered and consists of 28 items and no certification is required to administer it. ${ }^{28} \mathrm{~A}$ report is generated with composite scores for each of the four domains and a description of what their score means. The Emotional Intelligence Appraisal demonstrates strong reliability.

The Emotional Competence Inventory (ECI) is a 360-degree tool designed to assess the emotional competencies of individuals and organizations. ${ }^{40}$ It measures 18 competencies areas that receive a competency level score which is available in the report and indicates the level that is most characteristic of the participant's day-to-day work behaviors based on the feedback of others. Overall, the reliability of the ECI is considered good, however the "self" rating reliability is not as strong. Lastly, an overall validity study of the self-scored version of ECI demonstrated good construct, discriminant, and criterion validity.

The Emotional and Social Competency Inventory (ESCI) is a $360^{\circ}$ survey designed to assess 12 competencies of ability based on the earlier ECI. ${ }^{29}$ The ESCI measures the demonstration of individuals' behaviors, through their perceptions (self-scores) and those of their raters (others' scores), making it distinct from measures of EQ that assess ability or personality preferences. ESCI data is scored against a frequency range. Respondents are asked to assess the behaviors captured within each item on a 5-point scale ranging from one (never) to five (consistently) and an ESCI report is generated. Strength is indicated when participants' scores are $\geq 85 \%$ of the scale (a score of 4.3 ) which means that others perceive them to be demonstrating that competency often or consistently. The ESCI shows participants how others experience their behavior in terms of the consistency with which they demonstrate emotional and social competencies. Over 160,000 ESCI and ECI assessments have been processed and it has strong indicators of reliability.

The Emotionally Intelligent Leadership for Students (EILS) Inventory is a self-report assessment of emotionally intelligent leadership in the context of a student environment. ${ }^{35}$ The goal of the EILS is to serve as a learning tool for high school, college/university, or graduate school students and includes three key domains of consciousness of context, consciousness of self, and consciousness of others. The EILS inventory includes 19 statements assessed on a five-point Likert scale and a score is generated for each of the three domains/constructs from 8 to 40. Reliability was tested and each scale achieved a strong level of reliability.

\section{Strategies for EQ tool implementation}

Zeidner and colleagues ${ }^{41}$ identified seven characteristics for successful EQ programs: clear objectives and outcomes, educational context of the program, full integration into the curriculum, direct application of EQ to one's field, trainer/faculty development, and appropriate evaluation of the program. By incorporating EQ into the curriculum and not as just an add-on seminar or workshop, students are more likely to see EQ as an integral component of their education and 
training. Schools should also consider and evaluate the best process for standardized programming, effective teaching and assessment methods, assessment tools, and faculty training. School assessment committees should consider collecting data that shows continuous development of EQ abilities within both the didactic and experiential curriculum. Curriculum committees should consider identifying courses where EQ is first introduced and later developed. Skills and laboratory courses that are equipped to measure EQ development may provide critical data to demonstrate its systematic development. In addition, inclusion of EQ within social and administration courses may provide some applicability of EQ in leadership development, business and project management, and entrepreneurship. The co-curricular outcomes should also include EQ as a learning competency. Collaboration with student organizations can allow for a more student-driven process for inclusion of EQ. In addition to the deliberate curriculum, personal development through regular reflection may allow for self-development and a conscious effort by students to work on their EQ as a life-long competency rather than an isolated outcome. Institutions should identify faculty members with interest in EQ and facilitate further training in this arena through resource support and workload allocation. Only with well-qualified faculty can EQ be incorporated into the curriculum systematically. When possible, schools should pursue interprofessional collaboration with other programs, such as psychology, education, or other healthcare professions, to leverage the progress that other programs are making in the arena of EQ.

\section{Emotional Intelligence Applicability}

Standards 4 of the American Council for Pharmacy Education (ACPE) accreditation guidelines focus on personal and professional development with key elements being self-awareness, leadership, innovation, and professionalism, all of which have the underpinnings of emotional intelligence. ${ }^{42}$ Additional elements of emotional intelligence that are important for professional identify and practice may include mental health/well-being, clinical performance, and communication. Table 2 illustrates example cases for practical applicability of EQ in pharmacy practice. ${ }^{4,7-10,12,14-}$ $17,20,21,24,35,36,43-52$

\section{Professionalism}

Professionalism continues to be a competency that is challenging to teach. ${ }^{43,44}$ The term is nebulous and encompasses a variety of behaviors and values including volunteerism, respect, punctuality, enthusiasm for learning, interprofessional collaboration, patient interaction, leadership activities, among others. Taylor and colleagues ${ }^{45}$ proposed that, in order to be a professional, one must have both a cognitive knowledge base to understand the situation and a moral base to respond appropriately to the situation. There are several techniques to improve professionalism including role modeling, experiential learning, mentorship, and others. ${ }^{46}$ Role modeling can be an excellent way to develop pharmacy professionals but it is incumbent upon the student to observe and understand the moral basis of the behaviors they are expected to emulate. For the observing student, the mentor's private analysis of every situation may still be a mystery. Therefore, Taylor and colleagues ${ }^{45}$ suggested that EQ may be the basis for teaching professionalism as it encompasses several intangible competencies; self-awareness, self-control, social awareness, and relationship management, which are key in developing a true professional.

\section{Mental Health/ Wellbeing}

Stress can have negative health outcomes including anxiety, weight gain, and cardiovascular disease, among others. ${ }^{47}$ Doctor of pharmacy students report high levels of stress likely related to a variety of sources including academics, family expectations, personal relationships, and uncertainty about the future. ${ }^{48}$ The transition to professional school can be difficult and stressful for most students. Pau and colleagues ${ }^{16}$ found that dental students with high levels of EQ reported less perceived stress perhaps due to their ability to regulate their mood, develop relationships that help them cope with hardships, and their ability to empathize with others. Arora and colleagues ${ }^{4}$ found similar results with medical students who were performing surgical tasks. Students with higher EQ traits had lower self-reported stress and lower objective stress as measured by elevation in heart rate during surgery. Among nursing students, Por and colleagues ${ }^{17}$ also found a positive relationship between EQ, wellbeing, and problem-focused coping, concluding that the ability to manage emotions can contribute to greater subjective well-being. Schutte found that EQ can be protective against negative affect and is associated with greater life satisfaction. ${ }^{49}$ The literature suggests that EQ may contribute to wellbeing and good mental health among students. ${ }^{12,16,17,36,48,50}$

\section{Clinical Performance}

Experiential education is a crucial part of the Doctor of Pharmacy curriculum and is a necessary element for developing a novice student into a practice-ready graduate. However, like any social situation, experiential education can 
be fraught with personality conflicts, high workload, and emotionally draining patient interactions. McCloughen and colleagues ${ }^{15}$ discussed the use of emotionally intelligent behaviors in navigating tough interpersonal situations with staff during clinical placement and found that EQ techniques such as self-reflection, self-regulation, and empathy were key in managing challenging interpersonal situations. In a study measuring EQ and clinical performance among dental students, Victoroff and colleagues ${ }^{21}$ found that competencies related to self-management (self-control, achievement orientation, initiative, trustworthiness, conscientiousness, adaptability, and optimism) were a strong predictor of clinical performance as measured by clinical preceptor feedback. While the literature is limited in the arena of EQ and experiential education, the tenets of EQ including the management of one's own and other's emotions, appear to be necessary in succeeding in clinical practice.

\section{Leadership}

Leadership is defined as being able to demonstrate responsibility for creating and achieving shared goals, regardless of position..$^{20} \mathrm{EQ}$ is an important ingredient in effective leadership. ${ }^{9,10,20,24,51,52}$ The Emotionally Intelligent Leadership (EIL) model combines both EQ and leadership in an effort to highlight the importance of self-management and social aptitude when describing leadership qualities. ${ }^{35} \mathrm{EQ}$ is key in identifying when to step in as a leader, when to delegate work, when to provide emotional support, and when to step back. While the literature is still limited on EQ and leadership, it is likely that having a high level of EQ would be useful for any budding leader. ${ }^{52}$

\section{Professional Communication}

Professional communication is not just the ability to relay information in an eloquent and efficient manner. It also requires the ability to use the right language for the right situation, the ability to read the emotions in others, the ability to empathize in a sincere manner, and the ability to manage your own emotions so as not to escalate a difficult situation. Lust and colleagues ${ }^{14}$ argued that EQ should be incorporated into professional communications coursework so that students are introduced to the various aspects of communication including empathy, relationship building, non-verbal cues, among others. Galal and colleagues ${ }^{7,8}$ reported improvement in student social emotional competence through directed feedback in a professional communication skills course.

\section{Emotional Intelligence Implementation}

Factors related to EQ such as self-awareness, empathy, and self-regulation are important for any healthcare professional within both the direct patient care context and interprofessional collaboration. The ability to manage their emotions, adapt to new circumstances, and manage stress is necessary for all pharmacists and pharmacy students in today's practice environment. The ACPE standards have a strong emphasis on the affective domain, especially EQ abilities, such as self-awareness. ${ }^{42}$ Several considerations exist including systematic implementation and choice of assessment/measurement tool.

\section{Future Opportunities for Research}

Future research should include strategies for longitudinal and systematic development of EQ abilities, assessment of EQ in experiential education, and patient outcomes related to EQ. Co-curricular integration of EQ training is also an area of possible research. While it is unclear whether any specific teaching modality is superior in providing EQ training for pharmacy education, simulations or role playing with standardized patients can be useful in developing student EQ and for providing formative feedback for students. ${ }^{7,8}$ Other modalities include book readings, self-reflection, coaching, group discussion, and mentorship. However, more research is needed to identify evidence-based modalities that can be used for EQ development, whether students' EQ training can influence their academic success, build resistance from academic difficulty, increase the ability to provide compassionate and competent patient care, and increase grit and optimism. Additionally, more research is needed on EQ development in interprofessional education and should be an area of inquiry.

In addition, the role of EQ in stress management and burnout should be areas for future research. While there is some evidence that EQ has a role in managing perceived stress, more research in this area, especially interventional, will provide some direction as to methods that can improve student wellbeing and mental health. While the current literature demonstrates improvement in EQ, there is a dearth of literature that describes sustained and longitudinal improvements of EQ across the pharmacy curriculum, especially experiential education. However, some measures of EQ have an inherent positive bias towards women (eg, MSCEIT), and are subject to cultural norms. ${ }^{53}$ Inquiry into how this may impact implementation of EQ evaluation in pharmacy academia is worthy of further study. 
In addition, there is very little evidence demonstrating the long-term retention of EQ skills and whether these skills actually translate to clinical practice. Further, the question as to whether an emotionally intelligent pharmacist provides better care than one who is less emotionally competent remains unanswered. Data extrapolated from medicine would suggest that higher EQ is related to better outcomes and higher patient satisfaction, however more research is needed in pharmacy practice. ${ }^{5,22}$ Even though EQ was not theorized by the health professions, it would be ideal to validate EQ assessment tools for utilization in the health professions, depending on need of the profession, and have specific guidance on applicability for the tools overall.

\section{CONCLUSION}

This article highlighted current literature on EQ in medicine, nursing, and pharmacy education, and provided an overview of various tools used in assessing EQ. A majority of the tools were ability-based, trait-based, or mixed assessments and covered components such as professionalism, well-being, leadership, and professional communication. Implementation of EQ in pharmacy curriculum should include choosing an appropriate assessment and using feasible strategies. While there has been significant advancement in this area, several opportunities exist for ongoing inquiry especially in the pharmacy education literature.

\section{REFERENCES}

1. Salovey P, Mayer JD. Emotional Intelligence. Imagin Cogn Pers. 1990;9(3):185-211.

2. Mayer J, Salovey P, eds. What is Emotional Intelligence? New York, NY: Basic Books 1997

3. O'Connor PJ, Hill A, Kaya M, Martin B. The Measurement of Emotional Intelligence: A Critical Review of the Literature and Recommendations for Researchers and Practitioners. Front Psychol. 2019;10:1116. Published 2019 May 28. doi:10.3389/fpsyg.2019.01116

4. Arora S, Russ S, Petrides KV, Sirimanna P, Aggarwal R,Darzi A, Sevdalis N. Emotional intelligence and stress in medical students performing surgical tasks. AcadMed. 2011;86:1311-7

5. Cherry MG, Fletcher I, Berridge D, O'Sullivan H. Do doctors' attachment styles and emotional intelligence influence patients' emotional expressions in primary care consultations? An exploratory study using multilevel analysis. Patient Educ Couns. 2018;101(4):659-664. doi:10.1016/j.pec.2017.10.017

6. Foster K, Fethney J, McKenzie H, Fisher M, Harkness E, Kozlowski D. Emotional intelligence increases over time: A longitudinal study of Australian pre-registration nursing students. Nurse Educ Today. 2017;55:65-70. doi:10.1016/j.nedt.2017.05.008

7. Galal S, Carr-Lopez S, Seal CR, Scott AN, Lopez C. Development and assessment of social and emotional competence through simulated patient consultations. Am J Pharm Educ. 2012;76(7):132. doi:10.5688/ajpe767132

8. Galal S, Vyas D, Mayberry J, Rogan EL, Patel S, Ruda S. Use of Standardized Patient Simulations to Assess Impact of Motivational Interviewing Training on Social ${ }^{-}$Emotional Development. Pharmacy (Basel). 2018;6(3):65. Published 2018 Jul 11. doi:10.3390/pharmacy6030065

9. Haight RC, Kolar C, Nelson MH, Fierke KK, Sucher BJ, Janke KK. Assessing Emotionally Intelligent Leadership in Pharmacy Students. Am J Pharm Educ. 2017;81(2):29. doi:10.5688/ajpe81229

10. Hall CM, Enright SM, White SJ, Allen SJ. A quantitative study of the emotional intelligence of participants in the ASHP Foundation's Pharmacy Leadership Academy. Am J Health Syst Pharm. 2015;72(21):1890-1895. doi:10.2146/ajhp140812

11. Higuchi Y, Inagaki M, Koyama T, et al. Emotional Intelligence and its Effect on Pharmacists and Pharmacy Students with Autistic-like Traits. Am J Pharm Educ. 2017;81(4):74. doi:10.5688/ajpe81474

12. Lea RG, Davis SK, Mahoney B, Qualter P. Does Emotional Intelligence Buffer the Effects of Acute Stress? A Systematic Review. Front Psychol. 2019;10:810. Published 2019 Apr 17. doi:10.3389/fpsyg.2019.00810

13. Lin DT, Liebert CA, Tran J, Lau JN, Salles A. Emotional Intelligence as a Predictor of Resident Well-Being. J Am Coll Surg. 2016;223(2):352-358. doi:10.1016/j.jamcollsurg.2016.04.044

14. Lust E, Moore FC. Emotional intelligence instruction in a pharmacy communications course. Am J Pharm Educ. 2006;70(1):Article 6.

15. McCloughen A, Foster K. Nursing and pharmacy students' use of emotionally intelligent behaviours to manage challenging interpersonal situations with staff during clinical placement: a qualitative study. J. Clin. Nurs. 2018; 2 (7): 2699-2709

16. Pau AKH, Croucher R. Emotional intelligence and perceived stress in dental undergraduates. J Dent Educ. 2003;67:1023-8. 
17. Por J, Barriball L, Fitzpatrick J, Roberts J. Emotional intelligence: its relationship to stress, coping, well-being and professional performance in nursing students. Nurse Educ Today. 2011;31:855-60

18. Rode J, Brown K. Emotional Intelligence Relates to NCLEX and Standardized Readiness Test: A Pilot Study. Nurse Educ. 2019;44(3):154-158. doi:10.1097/NNE.0000000000000565

19. Sharon D, Grinberg K. Does the level of emotional intelligence affect the degree of success in nursing studies?. Nurse Educ Today. 2018;64:21-26. doi:10.1016/j.nedt.2018.01.030

20. Smith MJ, Wilson J, George DL, Laster K, Filippo C, Spies A. Emotional intelligence scores among three cohorts of pharmacy students before and after completing the University of Oklahoma College of Pharmacy's Leadership Degree Option Program. Curr Pharm Teach Learn. 2018;10(7):911-917. doi:10.1016/j.cptl.2018.04.001

21. Victoroff KZ, Boyatzis RE. What is the relationship between emotional intelligence and dental student clinical performance? J Dent Educ. 2013;77(4):416-26.

22. Weng HC, Steed JF, Yu SW, et al. The effect of surgeon empathy and emotional intelligence on patient satisfaction. Adv Health Sci Educ Theory Pract. 2011;16(5):591-600. doi:10.1007/s10459-011-9278-3

23. Moreno-Fernandez J, Ochoa JJ, Lopez-Aliaga I, et al. Lockdown, Emotional Intelligence, Academic Engagement and Burnout in Pharmacy Students during the Quarantine. Pharmacy (Basel). 2020;8(4):E194. Published 2020 Oct 22. doi:10.3390/pharmacy8040194

24. Buckley K, Bowman B, Raney E, et al. Enhancing the Emotional Intelligence of Student Leaders Within an Accelerated Pharmacy Program. Am J Pharm Educ. 2020;84(11):8056. doi:10.5688/ajpe8056

25. Latif DA. Using Emotional intelligence in the planning and implementation of a management skills course. Pharm Educ. 2004;4(2):81-89

26. Andrei F, Siegling AB, Aloe AM, Baldaro B, Petrides KV. The Incremental Validity of the Trait Emotional Intelligence Questionnaire (TEIQue): A Systematic Review and Meta-Analysis. J Pers Assess. 2016;98(3):261-276. doi:10.1080/00223891.2015.1084630

27. Bar-On, R. (2004). The Bar-On Emotional Quotient Inventory (EQ-i): Rationale, description and psychometric properties. In G. Geher (Ed.), Measuring emotional intelligence: Common ground and controversy. Hauppauge, NY: Nova Science.

28. Bradberry T, Greaves J. Emotional Intelligence 2.0. TalentSmart: San Diego; 2009. Emotional Intelligence Appraisal Product Fact Sheet. 2013 TalentSmart, Inc.

29. Boyatzis, R.E. (2007). The creation of the emotional and social competency inventory (ESCI). Hay Group research report.

30. Mayer JD, Salovey P, Caruso DR, Sitarenios G. Measuring emotional intelligence with the MSCEIT V2.0. Emotion. 2003;3(1):97-105. doi:10.1037/1528-3542.3.1.97

31. Palmer BR, Stough C, Harmer R, Gignac G. The Genos Emotional Intelligence Inventory: A Measure Designed Specifically for Workplace Applications. In: Parker J., Saklofske D., Stough C. (eds) Assessing Emotional Intelligence. The Springer Series on Human Exceptionality. Springer, Boston, MA. (2009). doi: https://doi.org/10.1007/978-0-387-88370-0_6

32. Salovey P, Mayer JD, Goldman SL, Turvey C, Palfai TP. Emotional attention, clarity, and repair: Exploring emotional intelligence using the Trait Meta-Mood Scale. In: Pennebaker JW, eds. Emotion, disclosure, \& health Washington: American Psychological Association;1995:125-154. https://doi.org/10.1037/10182-006

33. Petrides KV. Psychometric properties of the Trait Emotional Intelligence Questionnaire (TEIQue). In: Parker J., Saklofske D., Stough C. (eds) Assessing Emotional Intelligence. The Springer Series on Human Exceptionality. Springer, Boston, MA. 2009:85-101. doi: https://doi.org/10.1007/978-0-387-88370-0_5

34. Schutte NS, Malouff JM, Hall LE, Haggerty DJ, Cooper JT, Golden CJ. Development and validation of a measure of emotional intelligence. Pers Individ Dif. 1998; 25(2):167-177. doi: 10.1016/S0191-8869(98)00001-4

35. Shankman ML, Allen SJ, Miguel R. Emotionally intelligent leadership for students: Inventory, 2nd edition. San Francisco, CA: Jossey-Bass; 2015.

36. Ciarrochi J, Deane FP, Anderson S. Emotional intelligence moderates the relationship between stress and mental health. Pers Individ Dif. 2002; 32(2):197-209. https://doi.org/10.1016/S0191-8869(01)00012-5

37. Seal CR, Beauchamp KL, Miguel K, Scott AN, Naumann SE, Dong Q, and Galal S. Validation of a self-report instrument to assess social and emotional development. Research in Higher Education Journal. 2011;14:1-20.

38. Seal CR, Beauchamp KL, Miguel K, Scott AN. Development of a self-report instrument to assess social and emotional development. J Psychol Issues Organ Cult. 2011;2(2):1-14.

39. Seal CR, Miguel K, Alzamil A, Naumann SE, Royce-Davis J, Drost D. Personal-interpersonal competence assessment: a self-report instrument for student development. Res High Educ J. 2015;27:1-10 
40. Wolff SB. Emotional Competence Inventory (ECI) Technical Manual. 3rd ed. Philadelphia, PA: The Hay Group, McClelland Center for Research and Innovation; 2006

41. Zeidner M, Roberts RD, Matthews G. Can Emotional Intelligence Be Schooled? A Critical Review. Educ Psychol. 2002;37(4):215-231. doi: 10.1207/s15326985ep3704_2.

42. American Council for Pharmacy Education. Accreditation Standards and Key Elements for the Professional Program in Pharmacy Leading to the Doctor of Pharmacy Degree. Accreditation Council for Pharmacy Education. Chicago, Illinois. 2015.

43. Justice news. Hospital Pharmacist to Plead Guilty to Attempting to Spoil Hundreds of COVID Vaccine Doses. Accessed January 29, 2021. https://www.justice.gov/opa/pr/hospital-pharmacist-plead-guilty-attempting-spoilhundreds-covid-vaccine-doses

44. Joyner BD, Vemulakonda VM. Improving professionalism: making the Implicit more explicit. J Urol. 2007;177(6):2287-2291.

45. Taylor C, Farver C, Stoller JK. Perspective: Can emotional intelligence training serve as an alternative approach to teaching professionalism to residents? Acad Med. 2011 Dec;86(12):1551-4.

46. Cruess R, Cruess S, Steinert Y. (Eds.). Teaching Medical Professionalism: Supporting the Development of a Professional Identity (2nd ed.). Cambridge: Cambridge University Press. 2016. doi:10.1017/CBO9781316178485

47. McEwen BS. Protective and damaging effects of stress mediators. N Engl J Med. 1998;338(3):171-179.

48. Marshall LL, Allison A, Nykamp D, Lanke S. Perceived stress and quality of life among doctor of pharmacy students. Am J Pharm Educ. 2008;72(6):137.doi:10.5688/aj7206137.

49. Schutte NS, Malouff JM. Emotional intelligence mediates the relationship between mindfulness and subjective wellbeing. Personality and Individual Differences, 2011;50: 1116-1119.

50. Ghahramani S, Jahromi AT, Khoshsoroor D, Seifooripour R, Sepehrpoor M. The relationship between emotional intelligence and happiness in medical students. Korean J Med Educ. 2019;31(1):29-38. doi:10.3946/kjme.2019.116

51. Prati LM, Douglas C, Ferris GR, Ammeter AP, Buckley MR. Emotional intelligence, leadership effectiveness, and team outcomes. Int J Organ Anal. 2003;11(1):21-40. https://doi.org/10.1108/eb028961

52. Issah M. Change Leadership: The Role of Emotional Intelligence. SAGE Open. 2018;Jul-Sep:1-6.

53. Lopez-Zafra, E., Gartzia, L. Perceptions of Gender Differences in Self-Report Measures of Emotional Intelligence. Sex Roles 70, 479-495 (2014). https://doi.org/10.1007/s11199-014-0368-6 
Table 1. Select Studies Related to Emotional Intelligence in Pharmacy and Other Health Professions Students ${ }^{4-21}$

\begin{tabular}{|c|c|c|c|c|c|c|}
\hline Author & Title & $\begin{array}{l}\text { Study population, } \\
\text { location, sample size }\end{array}$ & EQ method, scale used & $\begin{array}{l}\text { Measurements, } \\
\text { Outcomes }\end{array}$ & Analysis method & Study Implications \\
\hline Arora $^{4}$ & $\begin{array}{l}\text { Emotional } \\
\text { intelligence and } \\
\text { stress in medical } \\
\text { students performing } \\
\text { surgical tasks }\end{array}$ & $\begin{array}{l}\text { US Medical/physician } \\
\text { undergraduates; } \mathrm{n}=17\end{array}$ & $\begin{array}{l}\text { State-Trait Anxiety } \\
\text { Inventory, continuous } \\
\text { heart rate (HR) } \\
\text { monitoring and the Trait } \\
\text { Emotional Intelligence } \\
\text { Questionnaire short } \\
\text { form (TEIQue-SF) }\end{array}$ & $\begin{array}{l}\text { Higher trait emotional } \\
\text { intelligence was } \\
\text { associated with higher } \\
\text { stress but students were } \\
\text { also more likely to } \\
\text { recover after stress }\end{array}$ & $\begin{array}{l}\text { Descriptive and } \\
\text { correlational analysis }\end{array}$ & $\begin{array}{l}\text { Higher emotional } \\
\text { intelligence can have } \\
\text { both positive and } \\
\text { negative consequences } \\
\text { sometimes resulting in } \\
\text { higher stress than } \\
\text { those with lower trait } \\
\text { emotional intelligence. }\end{array}$ \\
\hline Cherry $^{5}$ & $\begin{array}{l}\text { Do doctors' } \\
\text { attachment styles and } \\
\text { emotional } \\
\text { intelligence } \\
\text { influence patients' } \\
\text { emotional } \\
\text { expressions in } \\
\text { primary care } \\
\text { consultations? An } \\
\text { exploratory study } \\
\text { using multilevel } \\
\text { analysis }\end{array}$ & $\begin{array}{l}\text { Junior physicians in NW } \\
\text { England; } n=26\end{array}$ & $\begin{array}{l}\text { Mayer-Salovey-Caruso } \\
\text { Emotional Intelligence } \\
\text { Test, Experiences in } \\
\text { Close Relationships: } \\
\text { Short Form (ECR-SF) } \\
\text { questionnaire. The } \\
\text { Verona Coding } \\
\text { Definition of Emotional } \\
\text { Sequences were used to } \\
\text { code patient expressions } \\
\text { of emotional distress. }\end{array}$ & $\begin{array}{l}\text { EI associated with } \\
\text { frequency of patient } \\
\text { emotional expression }\end{array}$ & $\begin{array}{l}\text { Multilevel Poisson } \\
\text { Regression }\end{array}$ & $\begin{array}{l}\text { Physician EI may } \\
\text { influence patient } \\
\text { emotional expression }\end{array}$ \\
\hline Foster $^{6}$ & $\begin{array}{l}\text { Emotional } \\
\text { intelligence increases } \\
\text { over time: A } \\
\text { longitudinal study of } \\
\text { Australian pre- } \\
\text { registration nursing } \\
\text { students }\end{array}$ & $\begin{array}{l}\text { Nursing students at } \\
\text { metropolitan university in } \\
\text { Australia; } n=111\end{array}$ & $\begin{array}{l}\text { Assessing Emotions } \\
\text { Scale (AES) }\end{array}$ & $\begin{array}{l}\text { Students' EI increase } \\
\text { across the program; one } \\
\text { subscale of EI } \\
\text { (managing others' } \\
\text { emotions) was related to } \\
\text { higher academic } \\
\text { performance; significant } \\
\text { increase in the utilizing } \\
\text { emotions subscale } \\
\text { scores over time }\end{array}$ & Correlation & $\begin{array}{l}\text { Emotional mastery } \\
\text { skills can be learned }\end{array}$ \\
\hline $\mathrm{Galal}^{7}$ & $\begin{array}{l}\text { Development and } \\
\text { assessment of social } \\
\text { and emotional } \\
\text { competence through } \\
\text { simulated patient } \\
\text { consultations }\end{array}$ & $\begin{array}{l}\text { US } 1^{\text {st }} \text { year pharmacy } \\
\text { students; } n=212\end{array}$ & $\begin{array}{l}\text { Social Emotional } \\
\text { Development Inventory } \\
\text { (SED-I) }\end{array}$ & $\begin{array}{l}\text { Significant positive } \\
\text { correlation between } \\
\text { overall counseling } \\
\text { performance in the class } \\
\text { and scores on the SED-I } \\
\text { instrument for } \\
\text { connection to others and } \\
\text { influence orientation but } \\
\text { not for consideration or } \\
\text { connection factors }\end{array}$ & $\begin{array}{l}\text { Spearman's rho } \\
\text { correlation and student } \\
\text { t-test }\end{array}$ & $\begin{array}{l}\text { Role-play exercises in } \\
\text { patient consultations } \\
\text { can be used to develop } \\
\text { social emotional } \\
\text { competence in } \\
\text { pharmacy students and } \\
\text { SED-I can be used to } \\
\text { assess learning. }\end{array}$ \\
\hline $\mathrm{Galal}^{8}$ & Use of Standardized & US $1^{\text {st }}$ year pharmacy & Not truly measured & Assessment scores by & Paired t-tests, Wilcoxon & MI training can \\
\hline
\end{tabular}


Patient Simulations

to Assess Impact of

Interviewing (MI)

Training on Social-

Emotional

Development

Assessing

Emotionally

Intelligent

Leadership in

Pharmacy Students
Motivational students; $\mathrm{n}=205$

US Pharmacy stu
schools; $n=235$
TAs increased $8 \%$ after

MI training, and student

self-assessment scores

increased $22 \%$. tests, Pearson

correlations

Student scores were the highest for the

"consciousness of self" facet; EILI has primary

connections with pharmacy competencies related to

interprofessional

communication and

leadership.

\begin{tabular}{|c|c|c|c|}
\hline Hall $^{10}$ & $\begin{array}{l}\text { A quantitative study } \\
\text { of the emotional } \\
\text { intelligence of } \\
\text { participants in the } \\
\text { ASHP Foundation's } \\
\text { Pharmacy } \\
\text { Leadership Academy }\end{array}$ & $\begin{array}{l}\text { US Pharmacists in ASHP } \\
\text { Pharmacy Leadership } \\
\text { Academy (PLA); } \mathrm{n}=110\end{array}$ & $\begin{array}{l}\text { Emotional Quotient } \\
\text { Inventory, version } 2.0 \\
\text { (EQ-i 2.0) } \\
\text { Pharmacy leadership } \\
\text { demographic } \\
\text { questionnaire. }\end{array}$ \\
\hline Higuchi $^{11}$ & $\begin{array}{l}\text { Emotional } \\
\text { Intelligence and its } \\
\text { Effect on } \\
\text { Pharmacists and } \\
\text { Pharmacy Students } \\
\text { with Autistic-like } \\
\text { Traits }\end{array}$ & $\begin{array}{l}\text { Okayama University } \\
\text { pharmacists and pharmacy } \\
\text { students from Japan from } \\
\text { three universities; } \\
\text { pharmacist, } \mathrm{n}=373 \text {, and } \\
\text { student, } \mathrm{n}=341\end{array}$ & $\begin{array}{l}\text { Emotional Intelligence } \\
\text { Scale (EQS), Autism- } \\
\text { Spectrum Quotient } \\
\text { (AQ), Jefferson Scale of } \\
\text { Empathy } \\
\text { (JSE), and General } \\
\text { Health Questionnaire- } \\
12 \text { (GHQ) }\end{array}$ \\
\hline
\end{tabular}

\section{All subjects had an}

average level of EI

however PLA graduates

had higher total

emotional quotient score

compared to the control

group. In addition, PLA

graduates had higher

scores on several

composite factors such

as stress management

and decision-making.

AQ scores showed

significant inverse path

coefficients for JSE

scores and a positive

effect on GHQ

12 (GHQ)
Confirmatory factor

analysis to compare

EILI to the 2013 CAPE outcomes. Descriptive

statistics were

generated for each item

of the EILI

\author{
Sample $\mathrm{t}$ test \\ Correlation AQ scores \\ of both \\ students and \\ pharmacists showed \\ significant inverse path \\ PLA graduates have \\ the potential to be \\ better leaders versus \\ those who have not \\ completed the \\ program given the
}

coefficients for JSE

scores (c1: p,.001, c2:

$\mathrm{p}, .001)$ and

significant positive path

coefficients for GHQ

scores $(\mathrm{C} 1$ :

p,.001, C2: p,.001);

observed remaining

significant

direct effects of $\mathrm{AQ}$
EILI shows promise as an instrument for use

in assessing pharmacy students EI and leadership skills 


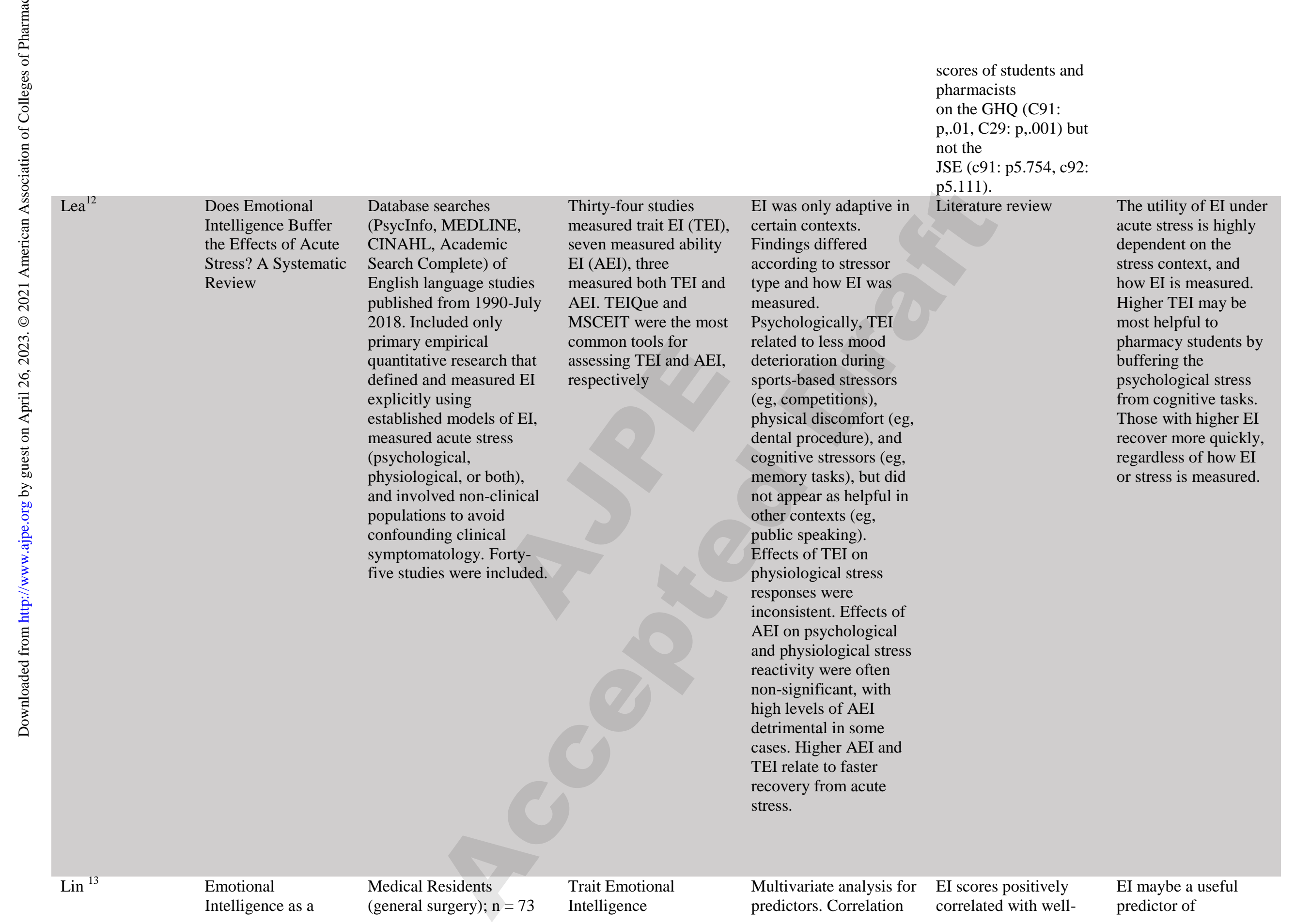




\begin{tabular}{|c|c|c|c|c|c|c|}
\hline & $\begin{array}{l}\text { Predictor of Resident } \\
\text { Well-Being }\end{array}$ & & $\begin{array}{l}\text { Questionnaire-Short } \\
\text { Form } \\
\text { Dupuy Psychological } \\
\text { General Well-Being } \\
\text { Index, Maslach Burnout } \\
\text { Inventory, and Beck } \\
\text { Depression Inventory- } \\
\text { Short Form. }\end{array}$ & $\begin{array}{l}\text { using Pearson } \\
\text { coefficients. }\end{array}$ & $\begin{array}{l}\text { being negatively } \\
\text { correlated with } \\
\text { depression, emotional } \\
\text { exhaustion, and } \\
\text { depersonalization. }\end{array}$ & $\begin{array}{l}\text { individuals who will } \\
\text { thrive in surgical } \\
\text { residency. } \\
\text { Interventions directed } \\
\text { at increasing EI may } \\
\text { improve residency } \\
\text { well-being }\end{array}$ \\
\hline Lust $^{14}$ & $\begin{array}{l}\text { Emotional } \\
\text { Intelligence } \\
\text { Instruction in a } \\
\text { Pharmacy } \\
\text { Communications } \\
\text { Course }\end{array}$ & $\begin{array}{l}\text { 1st year pharmacy } \\
\text { students at US Creighton } \\
\text { University School of } \\
\text { Pharmacy and Health } \\
\text { Professions, } \mathrm{n}=170\end{array}$ & $\begin{array}{l}\text { Two reflective } \\
\text { questions and student } \\
\text { feedback from a } \\
\text { Pharmacy } \\
\text { Communications course } \\
\text { that adopted Working } \\
\text { with Emotional } \\
\text { Intelligence to teach the } \\
\text { emotional competence } \\
\text { framework and its } \\
\text { application to pharmacy } \\
\text { practice }\end{array}$ & $\begin{array}{l}\text { Positive student } \\
\text { perceptions of EI } \\
\text { framework (self- } \\
\text { awareness, self- } \\
\text { regulation, motivation, } \\
\text { empathy, social skills) } \\
\text { and its usefulness and } \\
\text { applicability to } \\
\text { pharmacy practice and } \\
\text { management situations. } \\
\text { Students also reported } \\
\text { the ability to detect } \\
\text { weak EI in others. }\end{array}$ & Qualitative measures & $\begin{array}{l}\text { Incorporating EI } \\
\text { instruction into } \\
\text { pharmacy curricula } \\
\text { improves graduates' } \\
\text { insight into their own } \\
\text { and others' EI. Better } \\
\text { EI knowledge may } \\
\text { improve patient } \\
\text { outcomes through } \\
\text { improved social skills, } \\
\text { emotional control, and } \\
\text { empathy. }\end{array}$ \\
\hline McCloughen $^{15}$ & $\begin{array}{l}\text { Nursing and } \\
\text { pharmacy students' } \\
\text { use of emotionally } \\
\text { intelligent } \\
\text { behaviours to } \\
\text { manage challenging } \\
\text { interpersonal } \\
\text { situations with staff } \\
\text { during clinical } \\
\text { placement: A } \\
\text { qualitative study }\end{array}$ & $\begin{array}{l}\text { Final-year nursing and } \\
\text { pharmacy students at } \\
\text { University of Sydney, } \\
\text { Australia; } \mathrm{n}=20 \text {. }\end{array}$ & $\begin{array}{l}\text { Phase } 1 \text { surveyed } \\
\text { dentistry pharmacy and } \\
\text { nursing students' EI, } \\
\text { using the GENOS EI } \\
\text { Inventory and perceived } \\
\text { stress. A purposeful } \\
\text { sample of volunteers } \\
\text { from phase } 1 \text { with low, } \\
\text { medium, and high EI } \\
\text { scores were interviewed } \\
\text { for phase } 2 \text { in a semi- } \\
\text { structured format for } \\
45-60 \text { min. Students } \\
\text { described challenging } \\
\text { interpersonal clinical } \\
\text { situations and reflected } \\
\text { on emotions and } \\
\text { emotional management. }\end{array}$ & $\begin{array}{l}\text { Students used EI } \\
\text { behaviors to manage } \\
\text { challenging } \\
\text { interpersonal situations, } \\
\text { including student-staff } \\
\text { and intrastaff conflict, } \\
\text { discourteous behavior, } \\
\text { and criticism. Strategies } \\
\text { included reflecting and } \\
\text { reframing, being calm, } \\
\text { controlling discomfort, } \\
\text { and appropriately } \\
\text { expressing emotions. } \\
\text { Students were motivated } \\
\text { by a desire to act and be } \\
\text { seen as professional. }\end{array}$ & Qualitative measures & $\begin{array}{l}\text { Students with higher } \\
\text { EI can more } \\
\text { effectively manage } \\
\text { stressful interpersonal } \\
\text { interactions in the } \\
\text { clinical/workplace } \\
\text { environment }\end{array}$ \\
\hline $\mathrm{Pau}^{16}$ & $\begin{array}{l}\text { Emotional } \\
\text { intelligence and } \\
\text { perceived stress in } \\
\text { dental } \\
\text { undergraduates }\end{array}$ & $\begin{array}{l}\text { US Dental undergraduate } \\
\text { students; } n=213\end{array}$ & $\begin{array}{l}\text { Schutte Self-Report } \\
\text { Inventory, Perceived } \\
\text { Stress Scale (PSS-10) }\end{array}$ & $\begin{array}{l}\text { Low EI scorers } \\
\text { perceived more stress }\end{array}$ & $\begin{array}{l}\text { Multiple regression } \\
\text { analysis }\end{array}$ & $\begin{array}{l}\text { Female students } \\
\text { reported higher } \\
\text { perceived stress than } \\
\text { males. EI had a } \\
\text { negative association }\end{array}$ \\
\hline
\end{tabular}




$\begin{array}{lll}\text { Por }^{17} & \text { Emotional } & \text { US Nursing students } \mathrm{n}= \\ & \text { Intelligence: Its } & 130 \\ & \text { relationship to stress, } & \end{array}$

relationship to stress,

coping, well-being,

and professional

performance in

nursing students



Emotional

intelligence related

to NCLEX and

standardized

readiness test: A

pilot study
Sharon ${ }^{19} \quad$ Does the level of EI

affect the degree of

success in nursing

studies?
Schutte Emotional

Perceived Stress Scale

(PSS-10)

Ways of Coping Scale

Revised (WCS)

Satisfaction with Life

Scale (SWLS)

Short Nursing

Competence

Questionnaire (SNCQ)

Senior-level nursing

students in a baccalar

program at a Midwestern Test (MSCEIT V2.0)

US university; $\mathrm{n}=53$
Intelligence Scale

Higher EI was

correlated with greater

age, education,

wellbeing, and nursing

competency (most

positively correlated

factor), not correlated

with GPA, and inversely

correlated with stress.

Higher global EI scores were significantly related to better

performance on Kaplan

NAT (a comprehensive, end-of-program

achievement test) and

passing the National

Council Licensure

Examination (NCLEX-

$\mathrm{RN}$ ). Age and the

understanding emotions

branch of EI were

significant predictors of

NAT score. The

perceiving emotions and understanding emotions branches of EI were

significant predictors of

NCLEX-RN success.

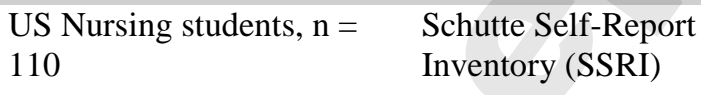

Positive correlation

between the level of EI

and the degree of

success in nursing

studies. EI levels

improved during the

2nd year of learning;

annual average grade

was related to EI rather

than psychometric

scores at time of

admission
Spearman correlation,

Cronbach's Alpha,

Kruskal Wallis,

Stepwise Multiple

Regression

Mann-Whitney test

(1)

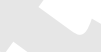

Multiple regression to test relationship of EI to Kaplan NAT performance. Logistic regression to test relationship of EI to NCLEX-RN success.

EI was correlated with positive outcome measures especially perceived stress in nursing students.

EI may predict nursing student performance on standardized tests for entry-level licensure. Nursing curricula may consider curricular development to improve EI, particularly understanding emotions, and nursing care.

$\begin{array}{ll}\text { Correlation } & \text { EI score inclusion in } \\ \text { admissions to } \\ \text { determine success and } \\ \text { average annual grade }\end{array}$




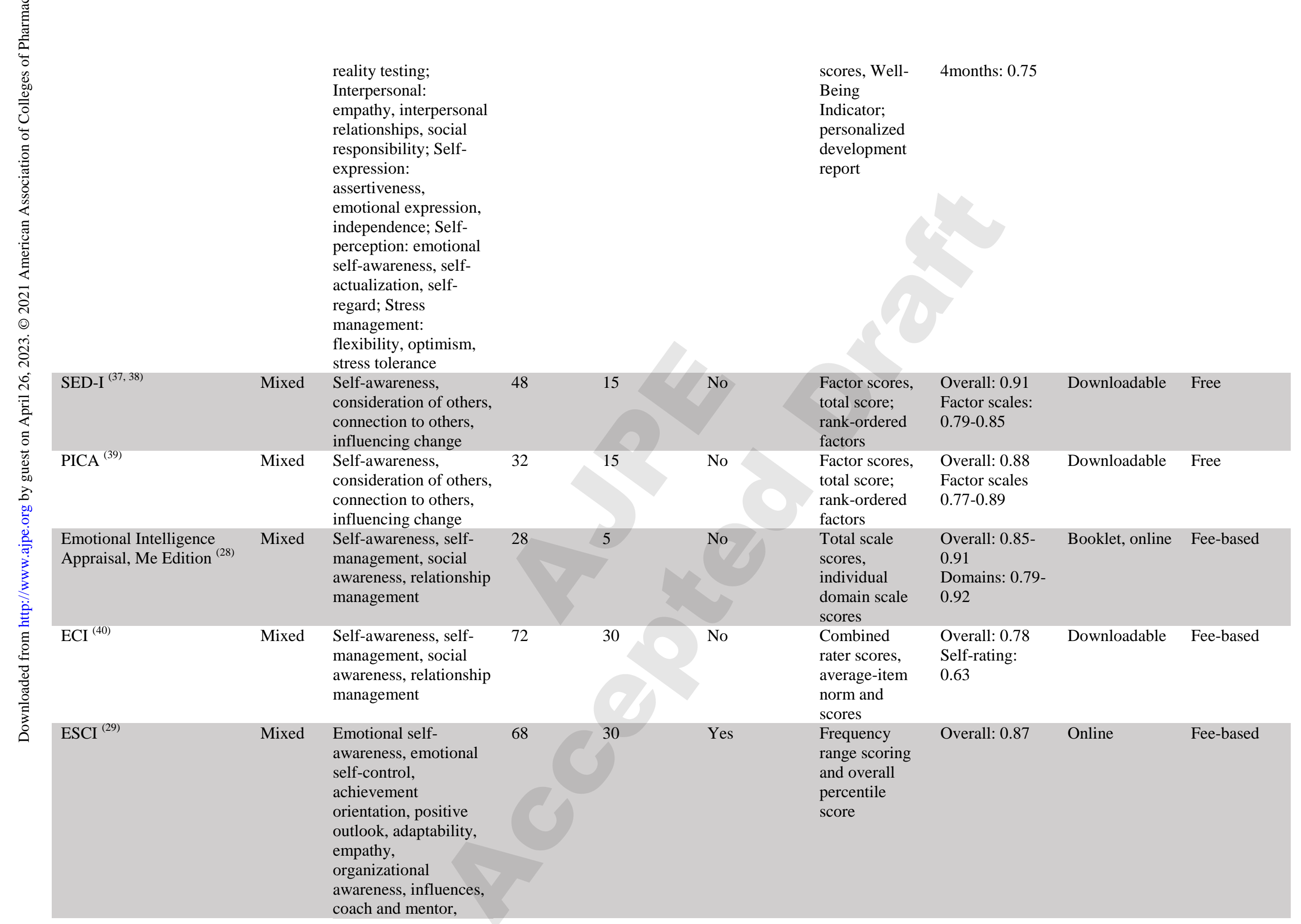


leadership, teamwork

EILS ${ }^{(35)}$

Consciousness of

19

context, consciousness

of self, consciousness

of others

$\begin{array}{lll}\text { Domain } & \text { Subscales: } & \text { Booklet, } \\ \text { scores, } & 0.73-0.82 & \text { downloadable } \\ \text { individual } & & \end{array}$

Fee-based

individual

statement

scores

EQ = emotional intelligence; MSCEIT V2.0 = Mayer-Salovey-Caruso Intelligence Test; Genos EI = Genos Emotional Intelligence Inventory; TMMS = Trait Meta-Mood Scale;

TEIQue = Trait Emotional Intelligence Questionnaire; AES = Assessing Emotions Scale; SREIT = Self-Report Emotional Intelligence Test; SSEIT = Schutte Self-Report

Emotional Intelligence Test; SSRI = Schutte Emotional Intelligence Scale or Schutte Self-Report Inventory; EQ-I 2.0 = Emotional Quotient Inventory 2.0; SED-I = Social and

Emotional Development Inventory; PICA = Personal-Interpersonal Competence Assessment; ECI = Emotional Competence Inventory; ESCI = Emotional and Social Competency

Inventory; EILS = Emotionally Intelligent Leadership for Students 
Figure 1. Example Cases for Practical Applicability of Emotional Intelligence (EQ)

EQ focus area

Example case

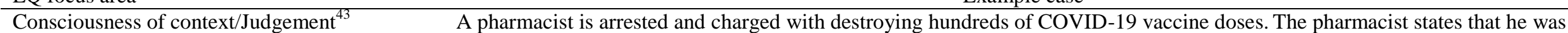
skeptical of vaccines and therefore he tampered with the vaccines, rendering them ineffective. Subsequently, several patients at the hospital's vaccine clinic received an ineffective vaccine. This criminal act led to the pharmacist's arrest and federal charges. There are several facets to this horrific story, however, a lack of emotional intelligence may also be to blame. The pharmacist did not regulate his negative emotions and biases towards vaccines and a lack of emotional self-control resulted in inappropriate behavior, subsequently destroying his career and endangering his patients.

Professionalism ${ }^{44,45}$

Role modeling ${ }^{46}$

Mental/Wellbeing ${ }^{4,12,16,17,36,47-50}$

Clinical Performance ${ }^{15,21}$
Maria is a respected pharmacist who runs her own community pharmacy. She is always professionally groomed, shows up on time, attends continuing education events, and prides herself in being a true professional. She holds her staff to the same standards and gets very emotionally charged when her staff is late to work or behaves in an unprofessional manner. She routinely reprimands her staff in public, sometimes with patients in the waiting area. The turnover rate in her pharmacy is quite high and she is unable to retain even her most professional employees who cite a hostile workplace environment as their reason for leaving. In several ways, Maria portrays the qualities of a true professional; however, she appears to be lacking in emotional intelligence, which prevents her from being aware of her own emotions, controlling her emotional response, and building relationships with her staff.

Shery is on her first rotation at an ambulatory care pharmacy practice which is located in a city with a diverse patient population including those with substance use disorders. During the first week of her rotation, she has a few patients who were intoxicated and called her names. She is shocked and embarrassed by the encounters and tells her preceptor, Matt, that she is not prepared to deal with such patients. Her preceptor who has been in the practice for over ten years understands her concerns and asks her to come to a patient-encounter where another belligerent and incoherent patient is coming in for a follow-up appointment. Matt demonstrates calmness while listening to the patient's concern but also is firm about actions and treatments that the patient needs to adhere to treat the condition. After the encounter, Matt discusses and breaks down how such a patient should be managed and how Sherry can build her skills in dealing with difficult patients by demonstrating empathy and firmness in a balanced and confident manner.

Jake's grades have always been stellar and he prides himself in never making anything less than a B in his courses. However, he is often excused from class for illness especially right before a big exam. On a self-reported burnout scale, Jake reports extremely high levels of burnout. Upon inquiry, Jake does not participate in any activities that are focused on his mental and physical wellbeing. He reports being stressed about his grades and overall school performance. He has no time for friends or family and rarely participates in social activities. He is the treasurer of a student organization; he hopes this will boost his curriculum vitae. On paper, Jake is a well-adjusted student who is succeeding in pharmacy school, however, in reality he is experiencing high levels of perceived stress with limited external coping skills.

Priya is currently on her advanced pharmacy practice experiences (APPE) and is assigned to the Internal Medicine team. Priya works hard to prepare for morning rounds and would like to provide stellar patient care. However, Priya gets very nervous and is unable to speak up during rounds. She is reserved and does not speak to any of the other trainees on her team. Lately, she has 
been feeling overlooked and in turn has lost interest in preparing for rounds. She feels cheated by her professors, who touted the important role of pharmacists on medical teams, which she has found to be untrue. Unfortunately for Priya, her lack of insight into why she was feeling overlooked and her reaction to this emotion, may have resulted in a substandard clinical experience.

Leadership $p^{9,10,20,24.35 .51}$

Professional Communication ${ }^{7,8,14}$

Abdul is a part of a team project. As a team member, he takes initiative, communicates regularly with his team, completes his work, uses creative techniques to develop a meaningful project, and is well like by his team. If needed, Abdul steps up and delegates work so that his team can concentrate on other classwork. While Abdul may not be the designated team lead, the team looks to him as the de facto leader. When Abdul feels stressed, he calls his parents on the phone, which helps him unwind. Abdul's understanding of the needs of others as well as his own self-regulation, indicates a high level of EQ, which in turn could be contributing to his success as a team leader.

José is a clinical pharmacist in the oncology clinic. He is diligent in making sure that the chemotherapy is appropriate and safe for his patients. To improve patient safety, he routinely provides counseling to patients about their chemotherapy and potential adverse drug effects. He is methodical in his delivery and makes sure all information is relayed in an effective manner. However, he is unable to empathize with his patients and maintains a stiff demeanor as he counsels his patients. He does not respond to their obvious distress and instead focuses on providing clinical information, which he believes is very important. In many ways, José is a competent pharmacist; however, his professional communication skills are lacking in a number of core competencies, including his ability to empathize with his patients and regulate his own emotions, so as to connect with his patients on a more personal level. 